\title{
Analisis Pengaruh PDB Iran, Kurs Dolar AS dan Inflasi Indonesia terhadap Nilai Ekspor Indonesia ke Iran Periode 2006.1-2017.4
}

\author{
Diautoriq Husain ${ }^{1}$, Bambang Sulistyono ${ }^{2}$, Didit Welly Udjianto ${ }^{3}$, Purkon Hidayat ${ }^{4}$ \\ 1,2,3Fakultas Ekonomi dan Bisnis UPN “Veteran” Yogyakarta \\ ${ }^{4}$ Fakultas Manajemen Tehran University, Iran \\ e-mail: diautoriqh@gmail.com
}

\section{Abstract}

During 2003-2017, the government continued to strive to increase the value of its exports, one of which was by opening alternative markets as broad as possible. This effort aims to minimize risk amid global uncertainty. Iran then became one of the alternative market options that Indonesia could choose to increase its exports if it mirrored Indonesia's exports to Iran during 2003-2017. This research uses quantitative analysis. In looking at the effect of Iranian GDP, US dollar exchange rate, and Indonesian inflation on the value of Indonesia's exports to Iran quarterly over the period 2006.1-2017.4, this study uses Ordinary Least Square (OLS) multiple linear regression analysis because the data in time series form. This study indicates that Iranian GDP, US dollar exchange rate, and Indonesian inflation simultaneously have a significant effect on the value of Indonesia's exports to Iran. However, Iranian GDP partially has a positive and significant effect, and the US dollar exchange rate has a significant and negative effect, while Indonesian inflation has no effect.

Keywords: Indonesia, international trade, Iran, multiple linear regression, Ordinary Least Square (OLS)

\section{Abstrak}

Selama tahun 2003-2017, pemerintah Indonesia terus berupaya untuk meningkatkan nilai ekspor, salah satunya dengan membuka pasar alternatif seluas-luasnya. Hal itu untuk meminimalisir resiko di tengah ketidakpastian global. Iran menjadi salah satu opsi pasar alternatif yang dapat dipilih Indonesia untuk meningkatkan ekspornya, jika berkaca pada jalannya ekspor Indonesia ke Iran selama tahun 2003-2017. Penelitian ini menggunakan analisis kuantitatif. Dalam melihat pengaruh Produk Domestik Bruto (PDB) Iran, kurs dolar Amerika Serikat 
(AS), dan inflasi Indonesia terhadap nilai ekspor Indonesia ke Iran secara triwulanan selama kurun waktu 2006.1-2017.4, penelitian ini menggunakan alat analisis regresi linier berganda Ordinary Least Square (OLS) karena data dalam bentuk time series. Hasil penelitian ini menunjukkan bahwa PDB Iran, kurs dolar AS, dan inflasi Indonesia secara simultan berpengaruh signifikan terhadap nilai ekspor Indonesia ke Iran. PDB Iran secara parsial berpengaruh positif dan signifikan, sementara kurs dolar AS berpengaruh negatif dan signifikan, sedangkan inflasi Indonesia tidak berpengaruh.

Kata kunci: Indonesia, Iran, Ordinary Least Square (OLS), perdagangan internasional, regresi linier berganda

\section{Pendahuluan}

Tahun 1983 menjadi titik mula Indonesia menggalakkan ekspornya, dengan mengubah strategi industrialisasi dari penekanan pada industri substitusi impor ke industri promosi ekspor. Posisi Indonesia sebagai negara yang memiliki kekayaan sumber daya alam melimpah menjadikan ekspor sebagai lokomotif penggerak pertumbuhan ekonomi. Maka, sejak saat itu ekspor menjadi prioritas utama pemerintah Indonesia untuk memacu pertumbuhan ekonominya. Bahkan, berselang tiga dekade setelah itu, nilai ekspor Indonesia selama 2003-2017 berada dalam tren meningkat walaupun geraknya fluktuatif.

\section{Grafik 1. Perkembangan Ekspor Indonesia Tahun 2003-2017}

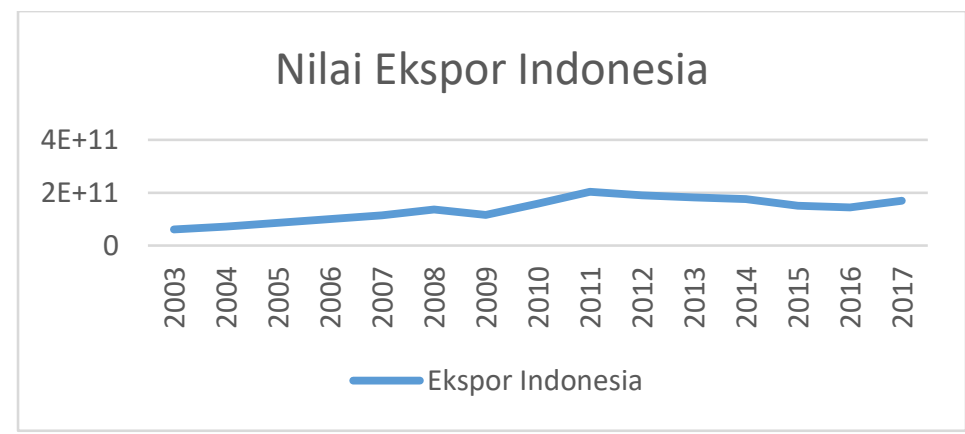

Sumber: Trade Map (data diolah penulis)

Terlihat pada grafik 1, nilai ekspor tertinggi Indonesia pernah menyentuh 203,5 miliar dolar AS pada tahun 2011. Meskipun setelahnya, torehan nilai itu tidak pernah 
tersentuh lagi. Namun, jika menilik kondisi perekonomian yang tengah lesu akibat ketidakpastian global, maka performa ekspor Indonesia sebetulnya dalam kondisi yang relatif baik. Terlebih lagi, perlahan pangsa ekspor Indonesia mulai meluas tidak hanya berpusat hanya di negara-negara Eropa saja, melainkan telah menjangkau ke banyak negara di Asia (Antaranews, 2019). Bahkan, dalam kurun waktu 2003-2017, negaranegara di Asia berpotensi besar menjadi tujuan utama ekspor Indonesia. Khususnya Asia Barat berpeluang besar menjadi pasar alternatif ekspor Indonesia berdasarkan besarnya nilai ekspor Indonesia ke enam negara Asia Barat berikut ini.

\section{Grafik 2 Ekspor Indonesia ke enam Negara Asia Barat}

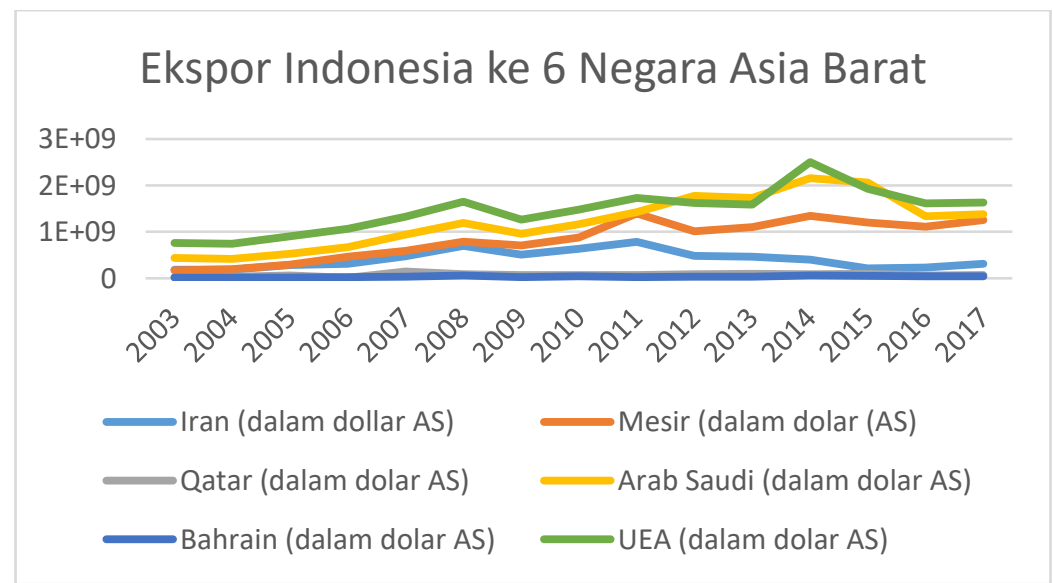

Sumber: Trade Map (data diolah penulis)

Grafik 2 menunjukkan ekspor Indonesia ke enam negara Asia barat, di antaranya Uni Emirat Arab (UEA), Arab Saudi, Mesir, Bahrain, Qatar, dan Iran bergerak fluktuatif, namun dalam tren yang meningkat. Bahkan, rata-rata ekspor Indonesia ke UEA mencapai 1,4 miliar dolar AS, yang tertinggi dibandingkan lima negara lainnya. Adapun yang menarik dari ekspor Indonesia ke enam negara tersebut adalah ekspor Indonesia ke Iran. Pasalnya, Iran berada dalam tekanan sanksi Amerika Serikat yang membuatnya tidak cukup leluasa melakukan perdagangan internasional. Merosotnya nilai ekspor Indonesia ke Iran pasca tahun 2013 dikarenakan sanksi tersebut (Hidayat, 2016). Meskipun demikian, alih-alih menjadi yang terendah, justru rata-rata ekspor Indonesia ke Iran mencapai 413 juta dolar AS, bahkan lebih besar dari ekspor Indonesia ke Qatar dan Bahrain yang masing-masing hanya 73 dan 36 juta dolar AS. Selain itu, pada tahun 2011, nilai ekspor Indonesia ke Iran mampu mencapai 785 juta dolar AS. 
Sanksi Amerika Serikat terhadap Iran telah melampaui empat dekade lamanya. Tahun 1979, James Earl Carter menjadi presiden AS pertama yang menjatuhkan sanksi terhadap Iran dengan Executive Order 12170 yang berisikan pembekuan aset-aset Iran senilai 12 miliar dolar AS (Moin, 1999). Selanjutnya, setiap presiden AS pada periode kepemimpinannya memiliki respon beragam terhadap Iran termasuk pengenaan sanksi terhadap Teheran. Apabila sanksi tersebut dilihat dalam rentang waktu 2003 hingga 2017, terdapat empat periode sanksi yang dijatuhkan AS terhadap Iran.

Tahun 2005, George W. Bush menerbitkan sanksi Executive Order 13382 yang berisikan pembekuan aset pihak-pihak yang dipandang terlibat dalam pengembangan nuklir Iran. Kemudian pada tahun 2010, semasa Presiden Barack Obama, Kongres AS mengesahkan Comprehensive Iran Sanctions, Accountability, and Divestment Act (CISADA). Sanksi tersebut berisikan pelarangan perusahaan-perusahaan asing mengekspor produk turunan minyak ke Iran. Kemudian, tahun 2012, Obama menerbitkan The Iran Threat Reduction and Syria Human Rights Act yang berisikan pelarangan perbankan asing bertransaksi dengan Bank Sentral Iran, CBI (Katadata.co.id, 2020).

Masih pada periode kepemimpinan yang sama, di akhir tahun 2013, sanksi atas Iran mulai dilonggarkan setelah terjadi perundingan awal Joint of Comprehensive Plan of Action (JCPOA). Negosiasi alot berjalan selama 20 bulan, akhirnya Iran bersama lima negara anggota tetap Dewan Keamanan PBB dan Jerman mencapai kesepakatan pada 14 Juli 2015 di Wina. Enam hari kemudian, Dewan Keamanan PBB mendukung perjanjian nuklir internasional ini dengan mengeluarkan resolusi 2231. Tapi kemudian, pergantian presiden AS pada tahun 2017 membuat hubungan AS dan Iran kembali memburuk, terutama dipicu langkah Presiden Donald Trump yang menarik negaranya keluar dari JCPOA pada 8 Mei 2018. Trump juga mengumumkan pemberlakuan kembali sanksi nuklir terhadap Iran.

Dalam situasi demikian, ekspor Indonesia ke Iran masih terus berlangsung. Bahkan, banyak komoditi Indonesia yang diminati oleh Iran. Misalnya saja, lima komoditi utama ekspor Indonesia ke Iran yang berasal dari sektor nonmigas, yang terdiri dari minyak nabati/hewani, aneka produk kimia, kertas dan produk turunannya, buah dan kacang-kacangan, dan bahan makanan lain. Adapun nilai ekspor per komoditi (dalam dolar AS) ditunjukkan pada tabel 1. 
Tabel 1. Lima Komoditi Utama Ekspor Indonesia ke Iran

\begin{tabular}{|l|l|l|l|l|l|}
\hline $\begin{array}{l}\text { Tahu } \\
n\end{array}$ & $\begin{array}{l}\text { Buah dan } \\
\text { Kacang- } \\
\text { kacangan } \\
\text { (dalam dolar AS) }\end{array}$ & $\begin{array}{l}\text { Kertas dan } \\
\text { Produk } \\
\text { Turunan (dalam } \\
\text { dolar AS) }\end{array}$ & $\begin{array}{l}\text { Aneka } \\
\text { Produk Kimia } \\
\text { (dalam dolar } \\
\text { AS) }\end{array}$ & $\begin{array}{l}\text { Minyak dan Lemak } \\
\text { Nabati/Hewani } \\
\text { (dalam dolar AS) }\end{array}$ & $\begin{array}{l}\text { Bahan } \\
\text { Makanan Lain } \\
\text { (dalam dolar } \\
\text { AS) }\end{array}$ \\
\hline 2003 & 6242 & 33633 & 967 & 32019 & 81 \\
\hline 2004 & 12836 & 41107 & 2309 & 25638 & 26 \\
\hline 2005 & 1447 & 82617 & 2635 & 84360 & 85 \\
\hline 2006 & 965 & 89432 & 2954 & 50639 & 24 \\
\hline 2007 & 660 & 128962 & 3154 & 168004 & 36 \\
\hline 2008 & 1175 & 154636 & 2225 & 334503 & 19 \\
\hline 2009 & 612 & 76409 & 6406 & 146305 & 115 \\
\hline 2010 & 591 & 103419 & 11918 & 279798 & 77 \\
\hline
\end{tabular}

Sumber: Trade Map (data diolah penulis)

Hingga kini, penelitian mengenai hubungan Indonesia dengan Iran dari kacamata ekonomi relatif masih sedikit jumlahnya. Padahal, selama ini hubungan perdagangan antara Indonesia dan Iran terus berlangsung, walaupun dalam tekanan sanksi Amerika Serikat. Oleh karena itu, penelitian ini akan menganalisis pengaruh PDB Iran, kurs dolar AS, dan inflasi Indonesia terhadap nilai ekspor Indonesia ke Iran. Meskipun hubungan perdagangan Indonesia dan Iran belum banyak diteliti, tetapi hubungan variabel PDB negara tujuan ekspor, kurs dolar AS, dan inflasi negara eksportir terhadap nilai ekspor untuk kasus lain sudah diteliti sebelumnya oleh Hendrati, Ignatia Martha dan Yunita Dwi S (2009), Mutia dan Sasana (2015), Akmal (2018), Anshari dkk (2017).

Urgensi penggunaan PDB Indonesia, PDB Iran, dan inflasi Indonesia sebagai variabel independen yang memengaruhi ekspor Indonesia ke Iran dalam penelitian ini adalah untuk menguraikan faktor-faktor yang mempengaruhi variabel dependennya dari sisi penawaran dan permintaan. Variabel PDB Indonesia dan inflasi Indonesia dapat digunakan untuk menakar seberapa besar pengaruh kondisi ekonomi domestik Indonesia, baik dari produktivitas maupun kestabilan terhadap ekspornya ke Iran. Penggunaan kedua variabel tersebut diharapkan bisa menguji validasi apakah penawaran ekspor Indonesia ke Iran memang dipengaruhi oleh dua faktor ini, sebagaimana teori yang ada sebelumnya pada kasus lain, atau sebaliknya.

Sementara itu, PDB Iran, selain menjadi variabel yang menentukan tingkat permintaan terhadap barang-barang yang diimpor dari Iran, juga berguna untuk melihat apakah ketidakstabilan ekonomi akibat embargo turut mempengaruhi permintaan impor Iran. Sebab, PDB Iran ini dapat menjadi ukuran untuk menilai tingginya tingkat 
permintaan impor Iran, sekaligus mendeteksi anomali sanksi terhadap ekspor Indonesia ke Iran.

Penelitian ini menggunakan metode kuantitatif dengan mengambil data dari sumber instansi resmi luar negeri, seperti Trade Map, Statistical Center of Iran, dan Federal Reserve Bank of St. Louis. Rentang waktu yang digunakan dalam penelitian ini adalah dari tahun 2006 hingga tahun 2017. Adapun untuk pengolahan datanya menggunakan analisis regresi linier berganda Ordinary Least Square (OLS) dengan bantuan software Eviews9. Metode OLS tersebut dianggap mampu menghasilkan estimasi terbaik dibandingkan metode lain bila memenuhi syarat-syarat asumsi klasik. Oleh karena itu, nilai estimasi dari metode OLS bersifat BLUE (Best, Linear, Unbiased, Estimator).

\section{Perdagangan Internasional}

Lintasan sejarah pemikiran ekonomi menunjukkan titik baru perdagangan internasional pada abad ketujuh belas Masehi dengan berkembangnya Merkantilisme. Merkantilisme berpijak pada pemikiran ekonomi yang meyakini sebanyak-banyaknya ekspor dan sedikit-dikitnya impor sebagai satu-satunya cara bagi sebuah negara untuk kuat dan kaya (Salvatore, 1997). Oleh karena itu, perdagangan internasional didefinisikan sebagai transaksi perdagangan antara subyek ekonomi negara yang satu dengan subyek ekonomi negara yang lain, baik mengenai barang ataupun jasa (Sobri, 2001). Subyek ekonomi yang dimaksud adalah penduduk yang terdiri dari warga negara biasa, perusahaan ekspor, perusahaan impor, perusahaan industri, perusahaan negara ataupun pemerintah yang tercermin pada neraca perdagangan. Dengan demikian, perbedaan sumber daya yang dimiliki oleh setiap negara menyebabkan terjadinya perdagangan internasional untuk mencapai skala ekonomi (economic of scale) (Oktaviani dan Novianti, 2009).

Di samping itu, berlangsungnya perdagangan internasional dipengaruhi oleh banyak faktor. Misalnya, dari sisi permintaan (impor) dipengaruhi oleh jumlah penduduk dan rata-rata pendapatan rumah tangga. Apabila pendapatan rata-rata rumah tangga mengalami kenaikan, jumlah komoditas yang diminta juga akan ikut bertambah banyak pada setiap harga tertentu. Sama halnya dengan jumlah penduduk, jika jumlah penduduk meningkat, jumlah komoditas yang diminta juga akan ikut bertambah banyak. Itulah mengapa kemudian antarnegara saling berdagang satu sama lain supaya memperoleh keuntungan (gains from trade) walaupun harus berspekulasi. Sebab, devisa yang diperoleh dari hasil ekspor akan digunakan untuk membiayai impor. Oleh karena itu, perdagangan internasional berkaitan dengan penawaran ekspor dan permintaan impor (Budiono, 1999). 
Perbedaan penawaran dan permintaan yang kemudian memicu perdagangan internasional dapat dilatarbelakangi oleh beberapa hal, di antaranya sebagai berikut.

a. Letak geografis dan sumber daya alam yang dimiliki suatu negara membuat negara tersebut tidak memiliki suatu komoditas yang dibutuhkan atau untuk diperdagangkan.

b. Ketidakmampuan negara dalam memanfaatkan komoditi tertentu secara lebih efisien.

Selanjutnya, proses penawaran dan permintaan antar dua negara membentuk perdagangan internasional, ekspor-impor, diilustrasikan melalui gambar berikut ini.

\section{Gambar 1 Harga Komoditi Relatif Equilibrium Setelah Perdagangan Ditinjau dari Analisis Keseimbangan Parsial}

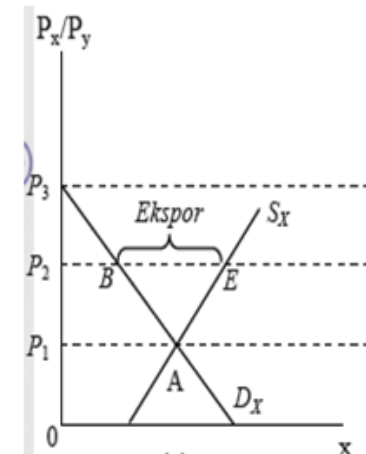

(a)

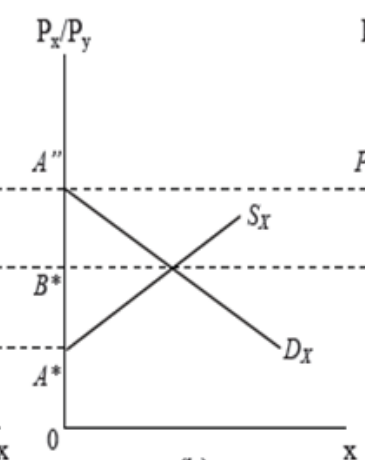

(b)

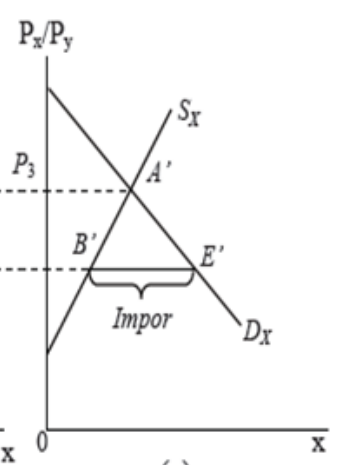

(c)

Sumber: Salvatore (1997)

Gambar 1 menggambarkan hubungan antar dua negara dalam dua keadaan, yakni dalam kondisi tanpa perdagangan dan terjadi perdagangan. Pertama, gambar (a) negara 1 dalam kondisi tanpa perdagangan, titik equilibriumnya berada di harga rendah, yaitu di titik P1. Gambar (c) menunjukkan negara 2 dalam kondisi tanpa perdagangan, titik equilibriumnya berada di harga tinggi, yaitu di titik P3. Gambar (b) menunjukkan perdagangan antara negara 1 dan negara 2, yang titik equilibriumnya berada di harga P3. Artinya, negara 1 dapat menetapkan harga barang menjadi lebih tinggi dari sebelumnya (P1), sedangkan negara 2 akan mendapatkan harga yang lebih rendah dari sebelumnya (P3), sehingga permintaan dan penawaran akan menemui titik equilibrium pada harga (P2), sebagai harga yang berlaku pada perdagangan antar kedua.

Pertemuan kurva permintaan dan penawaran pada titik equilibrium melambangkan harga relatif komoditi equilibrium yang akan menjadi dasar harga kedua 
negara tersebut. Jika harga relatif lain yang berlaku, maka kuantitas impor yang diinginkan tidak akan sama dengan kuantitas ekspor yang ditawarkan sehingga menimbulkan tekanan terhadap harga relatif kemudian harga tersebut menuju tingkat harga equilibrium yang baru.

\section{Gambar 2 Harga Relatif Komoditi dalam Kondisi Equilibrium}

\section{Setelah Berlangsungnya Perdagangan}

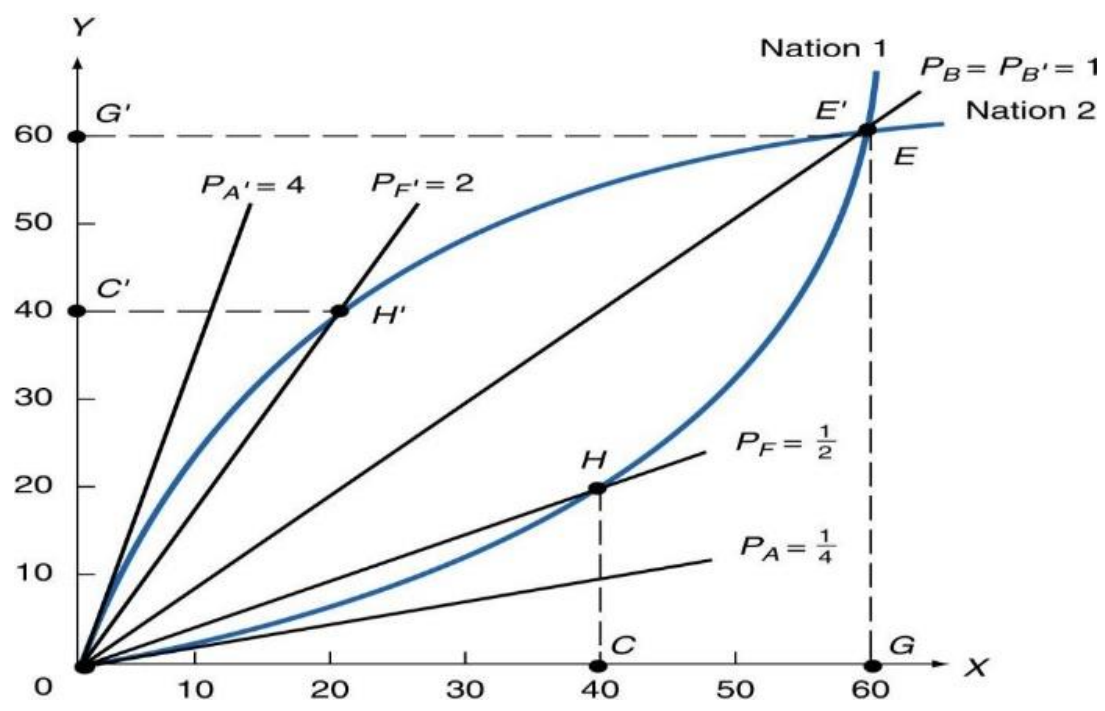

Sumber: Salvatore (1997)

Gambar 2 menggambarkan titik equilibrium pertemuan permintaan dan penawaran antar negara dalam hubungan perdagangan. Titik equilibrium tersebut berada pada titik $E$ yang disebut harga relatif equilibrium $P x / P y=P_{B}=P_{B^{\prime}}=1$. Artinya, tingkat harga relatif equilibrium tersebut menunjukkan keseimbangan perdagangan antara negara 1 dan negara 2, karena keinginan negara 1 (penukaran 60X untuk 60Y) sama dengan keinginan negara 2 (penukaran 60Y untuk 60X).

\section{Ekspor}

Ekspor merupakan penjualan barang-barang dalam negeri ke luar negeri. Awalnya, komoditi yang dihasilkan oleh produsen hanya ditawarkan di dalam negeri, tetapi seiring meningkatnya kebutuhan dunia akan barang dan jasa dan adanya negara yang tidak dapat memenuhi kebutuhannya sendiri maka negara yang dapat menghasilkan suatu komoditi dalam jumlah besar akan melakukan ekspor kepada negara yang membutuhkan komoditinya (Perdana, 2010). 
Atas dasar itu, ekspor merupakan upaya untuk melakukan penjualan komoditi yang dimiliki kepada bangsa lain dengan mengharapkan pembayaran dalam bentuk valuta asing (Amir, 2003). Nilai ekspor dan impor selain mempengaruhi neraca pembayaran, keduanya juga saling berpengaruh. Sebab, ekspor akan menghasilkan mata uang asing untuk membiayai impor, sehingga ekspor memberi suntikan dana sirkulasi dana pendapatan nasional.

Faktor-faktor yang mempengaruhi ekspor dapat dilihat dari sisi permintaan dan penawaran (Malian, 2016). Dari sisi penawaran dipengaruhi oleh harga domestik, harga ekspor, kapasitas produksi yang bisa diproduksi melalui investasi, kurs, kebijakan deregulasi, dan impor bahan baku. Sedangkan, dari sisi permintaan dipengaruhi oleh kebijakan devaluasi, kurs, harga domestik, dan pendapatan.

Permintaan ekspor sendiri diartikan sebagai permintaan pasar internasional terhadap komoditas yang dihasilkan oleh suatu negara. Permintaan tersebut didasari oleh kebutuhan konsumen. Setidaknya ada dua faktor yang mempengaruhi permintaan, yaitu: harga barang itu sendiri dan harga barang lain yang berkaitan erat dengan barang tersebut (Sukirno, 2012). Berbeda dengan permintaan ekspor, penawaran ekspor adalah penawaran komoditas yang dihasilkan suatu negara kepada pasar internasional. Hukum penawaran menyebutkan, jika harga suatu barang naik, jumlah barang yang ditawarkan akan naik, sebaliknya jika harga suatu barang turun, jumlah barang yang ditawarkan oleh produsen atau penjual akan turun dengan asumsi ceteris paribus (Joesron dkk, 2003).

Penghitungan harga jual ekspor umumnya dihitung melalui dua mekanisme, yakni Free on Board (FOB) dan Cost, Insurance, and Freight (CIF). Menurut laman resmi Kamar Dagang Internasional (ICC), keduanya mempunyai definisi sebagai berikut.

- FOB adalah harga jual saat naik kapal, sehingga pihak penjual bertanggung jawab dari mengurus izin ekspor sampai memuat barang di kapal yang siap berangkat.

- CIF adalah harga jual termasuk pengiriman barang dan premi asuransi, sehingga pihak penjual menanggung biaya sampai kapal yang memuat barang merapat di pelabuhan tujuan, dan penjual tersebut wajib membayar asuransi untuk barang yang dikirim. Akan tetapi, tanggung jawab penjual itu hanya sampai saat kapal berangkat dari pelabuhan keberangkatan.

Perbedaan antara FOB dan CIF dapat dilihat dalam ilustrasi di Gambar 3 berikut ini. 


\section{Gambar 3 Ilustrasi Perbedaan FOB dan CIF}

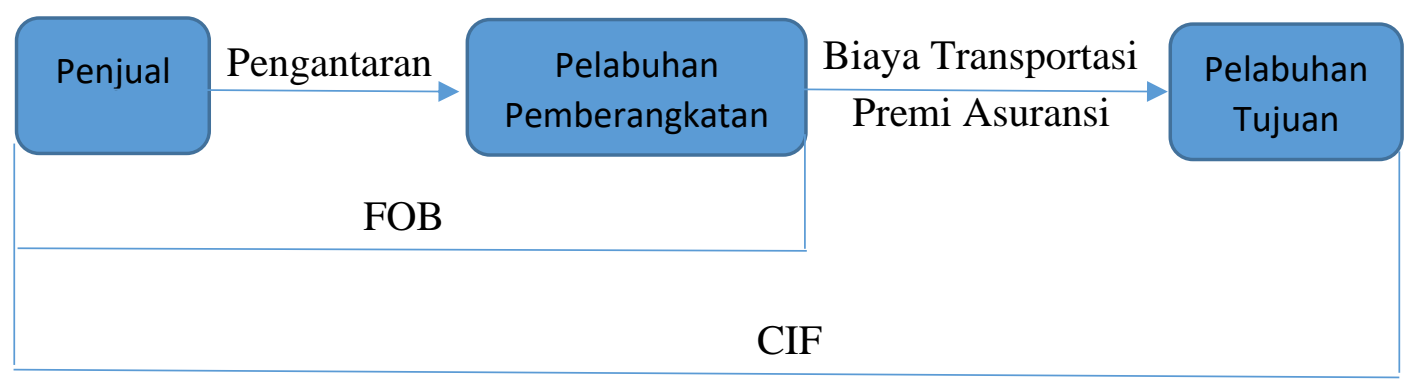

Sumber: ICC (International Chamber of Commerce)

\section{Hubungan Produk Domestik Bruto Negara Tujuan Ekspor Terhadap Ekspor}

Perdagangan internasional terbentuk dari penawaran (ekspor) dan permintaan (impor). Oleh karena itu, ekspor suatu negara akan menjadikan adanya impor dari negara lain. Untuk itu, peningkatan impor yang disebabkan oleh peningkatan PDB negara tujuan ekspor dapat ditinjau dari dua mekanisme, yaitu:

a. Peningkatan PDB negara tujuan ekspor menyebabkan peningkatan investasi sehingga kebutuhan barang impor negara tujuan ekspor, seperti bahan baku sebagai input proses produksi, menjadi meningkat.

b. Peningkatan PDB negara tujuan ekspor mendorong peningkatan kebutuhan produk final (final product) negara tujuan ekspor, lantaran tidak semua kebutuhan dapat diproduksi di dalam negeri, maka terjadi peningkatan impor.

\section{Hubungan Kurs Terhadap Ekspor}

Pada perkembangannya, kurs atau nilai tukar (exchange rate) ternyata menjadi kendala kelancaran perdagangan internasional (Christianto, 2013). Pasalnya, mata uang yang dimiliki oleh setiap negara saaat ini bukan hanya sekedar alat tukar semata, tetapi juga menjadi komoditas yang diperdagangkan bahkan dispekulasikan. Akibatnya, perbedaan mata uang tersebut menimbulkan masalah kurs sehingga perdagangan internasional tidak berjalan lancar.

Namun demikian, fungsi kurs sebagai alat pembayaran internasional sampai sekarang belum tergantikan. Sebab, kurs selain menjadi alat pembayaran transaksi internasional juga mempunyai catatan kurs resmi pada bank sentral (Putong, 2010). Khususnya dolar AS, kurs yang paling sering dipakai untuk pembayaran oleh mayoritas banyak negara, tak terkecuali Indonesia. Pada tahun 2017 hampir 94 persen nilai 
transaksi ekspor Indonesia dilakukan dalam transaksi dollar AS. Selain itu, karena nilainya yang cenderung stabil, dolar AS menjadi pilihan jaminan nilai dalam transaksi perdagangan internasional (CNBC, 2018). Ditambah lagi, dolar AS juga lebih mudah untuk ditukarkan ke berbagai valas negara lain. Oleh karena itu, fluktuasi kurs dolar AS berpengaruh terhadap nilai ekspor Indonesia. Sementara untuk lebih menjelaskan korelasi antara kurs dengan volume perdagangan, maka dapat dipahami melalui Model Mundell Fleming (Mankiw, 2008).

Model Mundell Fleming mengasumsikan tingkat harga tetap dan mobilitas modal sempurna menyebabkan fluktuasi jangka pendek dalam perekonomian terbuka kecil. Melalui model ini dijelaskan bahwa depresiasi atau apresiasi kurs akan menyebabkan perubahan pada ekspor maupun impor. Apabila kurs terdepresiasi, mata uang dalam negeri turun secara relatif terhadap mata uang asing, sehingga volume ekspor akan naik. Berikut ini, gambar yang menunjukkan Model Mundell Fleming.

\section{Gambar 4 Model Mundell Fleming}

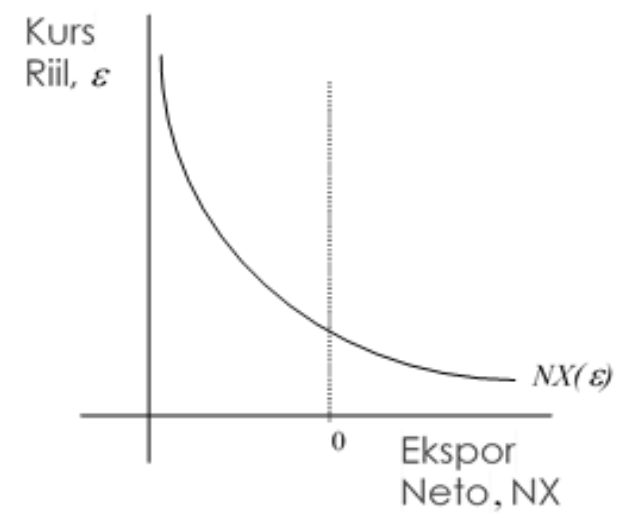

Sumber: Mankiw (2008)

Sebagaimana telah dikemukakan sebelumnya, resiko nilai tukar akibat perubahannya (volatile) yang berimplikasi pada volume perdagangan internasional. Dalam perkembangannya, perubahan kurs dapat memberikan dampak positif maupun negatif terhadap volume perdagangan.

Studi empiris Bourdon dan Korinek (2012) dikutip oleh Anshari dkk (2017) tentang pengaruh kurs terhadap perdagangan antara Chile dan Selandia Baru menunjukkan bahwa perubahan kurs mempengaruhi neraca perdagangan pada perekonomian terbuka. Sedangkan, pada penelitian yang lain menunjukkan perubahan kurs menyebabkan dampak yang ambigu pada volume perdagangan pada penelitian Rey (2006) yang dikutip Anshari dkk (2017). 


\section{Pengaruh Inflasi terhadap Ekspor}

Inflasi didefinisikan sebagai kenaikan terus-menerus dalam tingkat harga suatu komoditas akibat adanya kenaikan permintaan agregat atau penurunan penawaran agregat (Latumaerissa, 2012). Inflasi bisa disebabkan oleh permintaan agregat (demand pull inflation) dan penawaran agregat (cost pull inflation). Inflasi sebagai cerminan kenaikan harga-harga barang dan jasa, apabila mengalami kenaikan, dalam jangka pendek akan mendorong peningkatan produktivitas nasional. Namun, dalam jangka panjang dapat menurunkan daya saing yang berimbas pada penurunan ekspor (Silviana, 2016).

Berdasarkan uraian di atas, maka kerangka pemikiran konseptual penelitian ini tersusun sebagaimana dirangkum dalam Gambar 5 berikut ini.

\section{Gambar 5 Kerangka Pemikiran Konseptual}

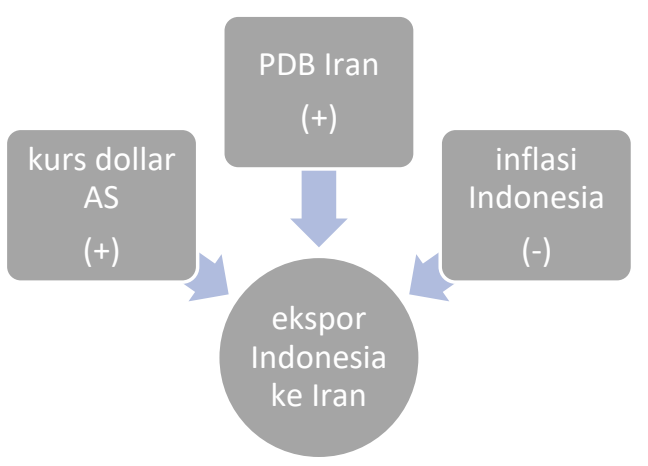

Peningkatan PDB Iran sebagai PDB negara tujuan ekspor akan menyebabkan peningkatan investasi dan kebutuhan produk final (final product), sehingga kebutuhan Iran terhadap impor bahan baku untuk input produksi juga ikut meningkat. Selain itu, peningkatan PDB tersebut juga mendorong peningkatan impor Iran, karena tidak semua kebutuhannya dapat dipenuhi oleh produksi dalam negeri. Sementara itu, kurs dolar AS sebagai alat pembayaran perdagangan internasional, akan meningkatkan nilai ekspor ketika kurs terdepresiasi. Namun sebaliknya, ketika kurs terapresiasi, maka nilai ekspor akan menurun. Terakhir, inflasi Indonesia mampu menurunkan nilai ekspor Indonesia ke Iran, karena akan meningkatkan biaya produksi dalam negeri Indonesia. Imbasnya, barang-barang ekspor Indonesia menjadi kalah saing sehingga nilai ekspornya menurun. 


\section{Metode Penelitian}

Penelitian ini menggunakan analisis kuantitatif dengan memakai uji statistik inferensial yang bertujuan untuk melihat derajat hubungan di antara dua atau lebih variabel. Metode analisis data yang digunakan Ordinary Least Square atau regresi linier berganda. Tujuan analisis regresi linier berganda adalah untuk mempelajari bagaimana eratnya pengaruh antara satu variabel independen dengan satu variabel dependen. Namun, bentuk data yang bervariasi perlu disamakan satuan antar variabel untuk meminimalkan kemungkinan terjadinya heteroskedastisitas karena transformasi yang menempatkan skala untuk pengukuran variabel (Gujarati, 2003). Karenanya, model fungsi regresi menggunakan model log-linier supaya lolos persyaratan heteroskedastisitas (Iqbal, 2015). Persamaan regresi dalam penelitian ini dapat dituliskan sebagai berikut:

$$
\begin{aligned}
& \text { LNEKS }=a+b 1 \text { LNPDBIRN + b2 LNKURS + b3 INFINA + e } \\
& \text { Keterangan: } \\
& \text { a } \\
& =\text { konstanta } \\
& b 1, b 2, b 3, b 4=\text { koefisien variabel } \\
& \text { LNEKS = Ekspor Indonesia ke Iran (\%) } \\
& \text { LNPDBIRN = PDB Iran (\%) } \\
& \text { LNKURS = Kurs Dolar AS } \\
& \text { INFINA = Inflasi Indonesia } \\
& \mathrm{e} \quad=\text { Error term }
\end{aligned}
$$

Data dan sumber data yang digunakan dalam penelitian ini adalah sebagai berikut.

Tabel 2 Data, Satuan, Simbol, dan Sumber Data

\begin{tabular}{|l|l|l|l|l|l|}
\hline No & Nama Variabel & $\begin{array}{l}\text { Satuan } \\
\text { Pengukuran }\end{array}$ & $\begin{array}{l}\text { Persamaan } \\
\text { Satuan }\end{array}$ & Sumber Data & Simbol \\
\hline 1 & $\begin{array}{l}\text { Nilai Ekspor } \\
\text { Indonesia ke } \\
\text { Iran }\end{array}$ & $\$$ & $\%$ & Trade Map & LNEKS \\
\hline 2 & PDB Iran & IRR & $\%$ & $\begin{array}{l}\text { Statistical } \\
\text { Center of } \\
\text { Iran }\end{array}$ & LNPDBIRN \\
\hline
\end{tabular}




\begin{tabular}{|l|l|l|l|l|l|}
\hline 3 & Kurs Dollar AS & Rp & $\%$ & $\begin{array}{l}\text { Federal } \\
\text { Reserve Bank } \\
\text { of St. Louis }\end{array}$ & LNKURS \\
\hline 4 & $\begin{array}{l}\text { Inflasi } \\
\text { Indonesia }\end{array}$ & $\%$ & $\%$ & $\begin{array}{l}\text { Federal } \\
\text { Reserve Bank } \\
\text { of St. Louis }\end{array}$ & INFINA \\
\hline
\end{tabular}

Berdasarkan tabel 2 di atas, terdapat perubahan satuan pada 3 variabel, pertama adalah nilai ekspor Indonesia ke Iran sebagai variabel dependen yang semula satuannya adalah dolar AS, kemudian diubah menjadi persen melalui rumus logaritma natural atau semilog dengan software Microsoft Office Excel. Kedua, variabel PDB Iran sebagai variabel independen yang semula satuannya adalah dolar AS kemudian diubah menjadi persen melalui rumus logaritma natural atau semilog dengan software Microsoft Office Excel. Ketiga, variabel kurs dolar AS sebagai variabel independen yang semula satuannya adalah Rupiah kemudian diubah menjadi persen melalui rumus logaritma natural atau semilog dengan software Microsoft Office Excel. Perubahan ini bertujuan untuk menyamakan satuan dan meminimalkan kemungkinan terjadinya heteroskedastisitas karena transformasi yang menempatkan skala untuk pengukuran variabel. Lalu, koefisien kemiringan $\beta i$ dapat menunjukkan elastisitas $Y$ terhadap $\mathrm{Xi}$, yaitu presentase perubahan dalam Y akibat adanya persentase perubahan dalam Xi (Gujarati, 2003). Untuk variabel terakhir, yaitu inflasi Indonesia sudah dalam bentuk persen.

\section{Definisi Operasional}

Terdapat dua variabel yang diteliti dalam definisi operasional, yaitu variabel dependen dan variabel independen. Dalam penelitian ini peneliti perlu memberikan gambaran dan batasan dari variabel yang menjadi pembahasan. Variabel - variabel akan diklasifikasi dan diidentifikasi sehingga variabel - variabel tersebut perlu didefinisikan secara operasional. Definisi operasional akan menunjuk alat pengambil data yang sesuai untuk digunakan. Penjelasan definisi operasional variabel untuk masing-masing variabel dan indikatornya adalah sebagai berikut:

\section{Variabel Independen}

\section{Produk Domestik Bruto Iran}

PDB Iran berdasarkan harga belaku dengan pendekatan pengeluaran, yakni kalkulasi nilai akhir dari konsumsi, investasi, belanja pemerintah, dan net ekspor. Satuan PDB adalah Riyal Iran.

\section{Kurs Dolar Amerika Serikat}


Nilai tukar resmi berdasarkan harga berlaku mengacu pada nilai tukar rata-rata triwulan dari dolar AS ke Rupiah yang ditentukan oleh otoritas nasional atau nilai tukar yang ditentukan dalam pasar nilai tukar yang disetujui secara hukum. Satuan kurs dolar AS adalah Rupiah.

\section{Inflasi Indonesia}

Inflasi Indonesia diukur dengan indeks harga konsumen mencerminkan persentase perubahan tahunan dalam biaya terhadap rata-rata konsumen dalam memperoleh sekeranjang barang dan jasa yang dapat diperbaiki atau diubah pada interval triwulanan. Satuan inflasi Indonesia adalah persen.

Variabel Dependen: Nilai Ekspor Indonesia ke Iran

Nilai ekspor Indonesia ke Iran adalah total nilai komoditi yang diekspor Indonesia ke Iran yang mengacu pada nilai Free on Board (FOB), yakni harga jual saat naik kapal di pelabuhan Indonesia, sebagaimana penghitungan harga ekspor internasional oleh ICC (International Chamber of Commerce). Satuan yang digunakan adalah dolar AS.

\section{Gambaran Umum Mengenai Empat Variabel yang Diteliti}

\section{Ekspor Indonesia ke Iran}

Nilai ekspor Indonesia ke Iran kuartal selama tahun 2006.1-2017.4 bergerak fluktuatif dengan rata-rata sebesar 115,353 juta dolar AS. Tercatat, nilai ekspor tertinggi pada kuartal keempat tahun 2010. Raihan itu diperoleh karena tren baik selama tahun 2010 yang disebabkan membaiknya kondisi perekonomian global pasca krisis finansial yang menimpa AS dan negara-negara Eropa yang meminimalisir ketidakpastian global. Ditambah lagi, tren positif ekspor Indonesia ke Iran terus berlanjut hingga tahun 2011. Namun, tak berlangsung lama, justru nilai ekspor Indonesia terus menurun hingga tahun 2016. Bahkan, pada kuartal pertama tahun 2016 menjadi titik terendah menyentuh 24,165 juta dollar AS. Hal ini tak lepas dari dampak sanksi AS terhadap Iran. Untungnya, digalakkannya kembali perundingan kerja sama ekonomi antara Indonesia dan Iran telah memberikan sentimen positif, sehingga tren ekspor Indonesia ke Iran mulai membaik kembali sejak kuartal kedua tahun 2016 hingga tahun 2017. 
Gambar 6 Nilai Ekspor Indonesia ke Iran

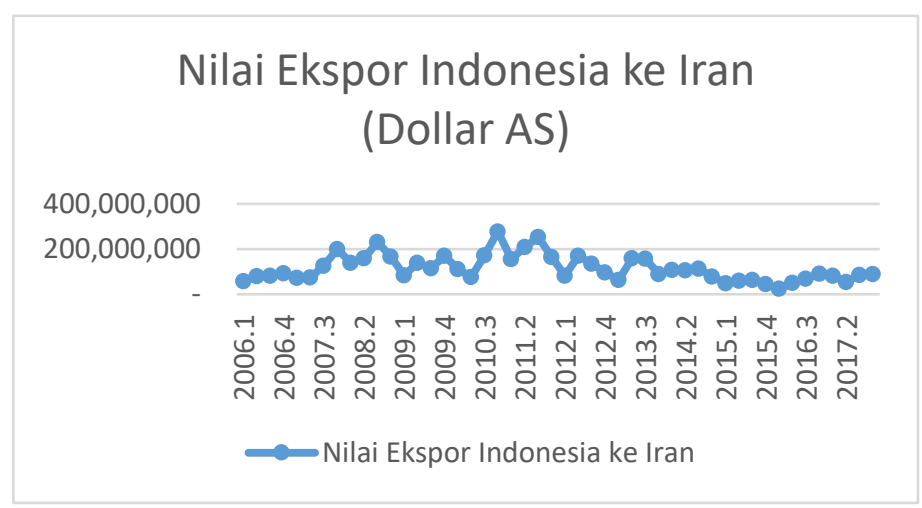

Sumber: Trade Map (data diolah penulis)

\section{Produk Domestik Bruto Iran}

PDB Iran secara kuartal selama kurun waktu 2006.1-2017.4 bergerak dalam tren positif. Akan tetapi, selama rentang waktu tahun 2012 hingga 2016, PDB Iran pernah beberapa kali mengalami penurunan. Menurut World Bank, penurunan PDB pada tahun 2012 dipicu oleh sanksi ekspor minyak mentah ke Eropa. Ketika Iran tengah dalam kondisi pemulihan ekonomi akibat sanksi, pada tahun 2015 perekonomian Iran kembali dihantam anjloknya harga minyak dunia. Padahal, sebagian besar pendapatan Iran dari sisi ekspor berasal dari sektor minyak mentah. Sedangkan, membaiknya tren PDB Iran sejak tahun 2016 tidak lepas dari pulihnya harga minyak mentah dunia, dan pelonggaran sanksi embargo Iran sejak 2015-2017.

\section{Gambar 7 PDB Iran}

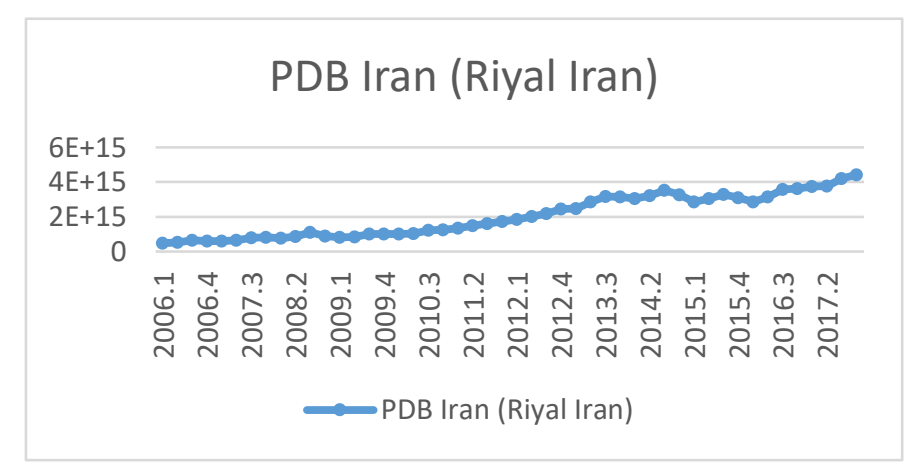

Sumber: Statistical Center of Iran (data diolah penulis) 


\section{Kurs Dolar AS}

Kurs dolar AS secara kuartal selama kurun waktu 2006.1-2017.4, berada dalam kondisi yang relatif stabil dengan rata-rata sebesar 10.732 rupiah. Meski dalam momentum tertentu sempat terdepresiasi, tetapi pelemahannya berlangsung normal. Dalam kurun waktu ini, tercatat nilai terendah terjadi pada kuartal kedua tahun 2011, senilai 8.597 rupiah. Nilai rupiah yang terapresiasi pada waktu itu dikarenakan tingginya ekspor Indonesia, sehingga nilai dolar AS terhadap rupiah terdepresiasi. Sementara, pada kuartal ketiga tahun 2015, kurs dolar AS berada di titik tertinggi, senilai 14.657 rupiah, lantaran ketidakpastian global yang berimbas pada terdepresiasinya rupiah terhadap dolar AS.

\section{Gambar 8 Kurs}

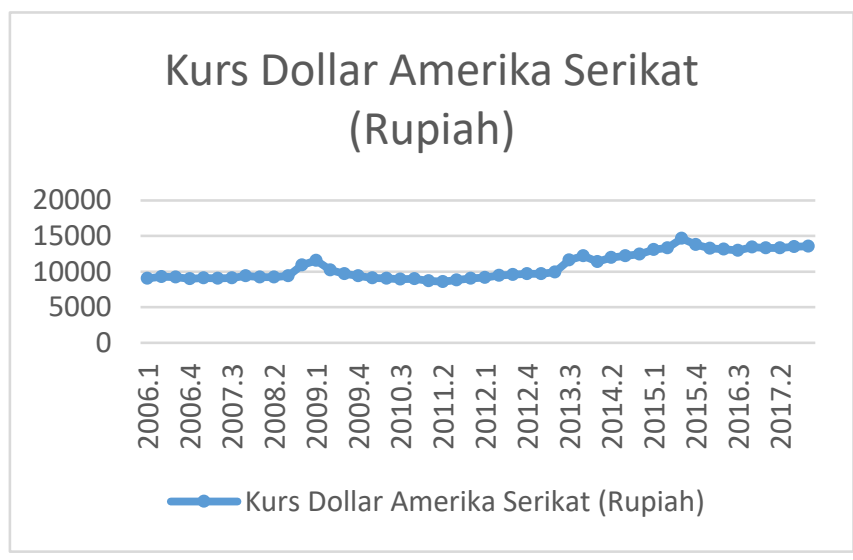

Sumber: Federal Reserve Economic Data (data diolah penulis)

\section{Inflasi Indonesia}

Inflasi Indonesia secara kuartal selama tahun 2006.1-2017.4 bergerak fluktuatif dengan rata-rata 1,4 persen. Meski pada beberapa momentum sempat mengalami kenaikan, maupun penurunan yang cukup signifikan, tetapi kenaikan inflasi selama kurun waktu itu cukup terkendali. Bahkan, tercatat nilai terbesar hanya 4,3 persen pada kuartal ketiga tahun 2013. Untungnya, setelah itu inflasi terus terjaga dibawah 2 persen. Artinya, selama kurun waktu ini, pergerakan tingkat inflasi cukup stabil dan tidak terjadi lonjakan angka ekstrem yang mengarah krisis. 


\section{Gambar 9 Inflasi Indonesia}

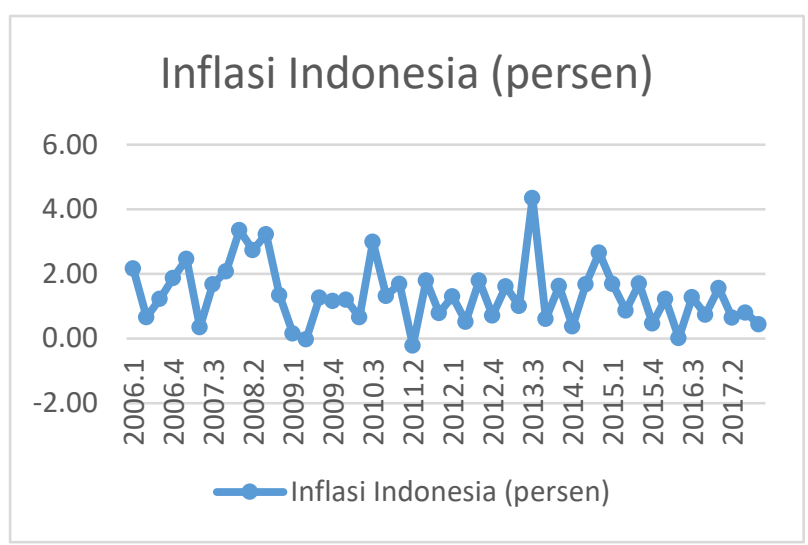

Sumber: Federal Reserve Economic Data (data diolah penulis)

\section{Analisis Pengaruh PDB Iran, Kurs Dolar AS dan Inflasi Indonesia terhadap Nilai Ekspor Indonesia ke Iran Periode 2006.1-2017.4}

Faktor-faktor yang mempengaruhi ekspor Indonesia ke Iran, yaitu produk domestik bruto Iran, kurs dolar AS, dan inflasi Indonesia, sebagai variabel independen diketahui melalui analisis regresi linier berganda dengan pendekatan Least Square (OLS) klasik. Pembuktian hipotesis dengan data yang tersedia akan dijelaskan melalui perhitungan dan pengujian-pengujian terhadap masing-masing koefisien regresi yang diperoleh dari program Eviews 9 dengan alat bantu komputer. Hasilnya adalah sebagai berikut.

\section{Koefisien Variabel}

\begin{tabular}{|l|c|c|c|}
\hline \multicolumn{1}{|c|}{ Variabel } & Koefisien & t-stats & Probabilitas \\
\hline C & 31,781 & 9,535 & 0,0000 \\
\hline LNPDBIRN & 0,307 & 2,314 & $0,0254^{*}$ \\
\hline LNKURS & $-2,612$ & $-4,909$ & $0,0000^{*}$ \\
\hline INFINA & 0,078 & 1,273 & 0,2095 \\
\hline
\end{tabular}

Keterangan: *signifikan $\alpha=5 \%$

Berdasarkan hasil olah data tersebut, maka dituliskan model persamaan sebagai berikut:

$$
\text { LNEKS = 31,781 + 0,307 LNPDBIRN - 2,612 LNKURS + 0,078 INFINA }
$$

Fungsi tersebut dapat diinterpretasikan sebagai berikut: 
1. Konstanta $a=31,781$. Artinya, jika variabel independen PDB Iran, kurs, dan Inflasi Indonesia bernilai nol (0), maka variabel dependen yaitu nilai ekspor Indonesia ke Iran sebesar 31,781.

2. PDB Iran memiliki koefisien regresi sebesar 0,307 yang menunjukkan jika terjadi peningkatan PDB Iran sebesar 1 persen, maka nilai ekspor Indonesia ke Iran akan mengalami peningkatan sebesar 0,307 persen (ceteris paribus).

3. Kurs dolar AS memiliki koefisien regresi sebesar -2,612 yang menunjukkan jika terjadi peningkatan kurs dolar AS sebesar 1 persen, maka nilai ekspor Indonesia ke Iran akan mengalami penurunan sebesar 2,612 persen (ceteris paribus).

4. Inflasi Indonesia memiliki koefisien regresi sebesar 0,078 yang menunjukkan jika terjadi peningkatan inflasi Indonesia sebesar 1 persen, maka nilai ekspor Indonesia ke Iran akan mengalami peningkatan sebesar 0,078 persen (ceteris paribus).

\section{Uji Statistik}

- Uji t

Hasil uji signifikansi parameter individual (uji t) pada regresi ditunjukkan oleh tabel berikut ini.

\section{Hasil Uji t}

\begin{tabular}{|l|c|c|}
\hline \multicolumn{1}{|c|}{ Variabel } & t statistik & t tabel $(\boldsymbol{\alpha}=\mathbf{5 \%})$ \\
\hline LNPDBIRN & 2,314 & \\
\hline LNKURS & $-4,909$ & 2,015 \\
\hline INFINA & 1,273 & \\
\hline
\end{tabular}

\section{a. Produk Domestik Bruto Iran}

Diketahui nilai t statistik variabel produk domestik bruto Iran lebih besar dari nilai t tabel $(2,314>2,015)$, maka dapat disimpulkan bahwa variabel produk domestik bruto Iran berpengaruh positif dan signifikan secara statistik terhadap variabel nilai ekspor Indonesia ke Iran.

\section{b. Kurs Dolar AS}

Diketahui nilai t statistik variabel kurs dolar AS lebih kecil dari nilai t tabel ($4,909<-2,015)$, maka dapat disimpulkan bahwa variabel kurs dolar AS berpengaruh negatif dan signifikan secara statistik terhadap variabel nilai ekspor Indonesia ke Iran.

\section{c. Inflasi Indonesia}

Diketahui nilai t statistik variabel Inflasi Indonesia lebih kecil dari nilai t tabel $(1,273<2,015)$, maka dapat disimpulkan bahwa variabel Inflasi Indonesia 
berpengaruh positif dan tidak signifikan terhadap variabel nilai ekspor Indonesia ke Iran.

- Uji F

Hasil Uji F statistik

\begin{tabular}{|l|c|c|}
\hline Variabel & F statistik & F tabel \\
\hline LNPDBINA & & \\
\cline { 1 - 1 } LNPDBIRN & 11,377 & 2,82 \\
\cline { 1 - 1 } LNKURS & & \\
\cline { 1 - 1 } INFINA & & \\
\hline
\end{tabular}

Hasil Uji F diperoleh nilai F statistik lebih besar dari nilai F tabel (11,377 > 2,82), maka dapat disimpulkan bahwa variabel independen, yaitu , PDB Iran, kurs dolar AS, dan inflasi Indonesia, secara bersama-sama berpengaruh signifikan terhadap variabel dependen, yaitu nilai ekspor Indonesia ke Iran.

- Uji $\mathbf{R}^{2}$

\section{Hasil Koefisien Determinasi $\mathbf{R}^{2}$}

\begin{tabular}{|l|c|}
\hline Variabel & R-square \\
\hline LNPDBINA & \\
\hline LNPDBIRN & 0,437 \\
\hline LNKURS & \\
\hline INFINA & \\
\hline
\end{tabular}

Diketahui nilai R-squared sebesar 0,437 maka dapat disimpulkan bahwa variasi variabel independen, yaitu PDB Iran, kurs dolar AS, dan inflasi Iran dapat menjelaskan variabel dependen, yaitu nilai ekspor Indonesia ke Iran sebesar 43,7 persen. Sementara sisanya 56,3 persen dijelaskan oleh variabel lain yang tidak dimasukkan dalam model ini.

\section{Uji Asumsi Klasik}

\section{- Uji Heteroskedastisitas}

Hasil Uji Heteroskedastisitas

\begin{tabular}{|l|l|l|l|}
\hline F-statistic & 0,322 & Prob. F(3,44) & 0,809 \\
\hline Obs*R-squared & 1,032 & Prob. Chi-Square (3) & 0,793 \\
\hline Scaled explained SS & 0,888 & Prob. Chi-Square (3) & 0,828 \\
\hline
\end{tabular}

Hasil uji heteroskedastisitas menggunakan Breusch-Pagan-Godfrey menunjukkan bahwa nilai Prob obs*R-squared sebesar 0793 lebih besar dari tingkat alpha 0,05 (5 persen), sehingga berdasarkan uji hipotesis, $\mathrm{H}_{0}$ diterima yang artinya tidak terjadi heteroskedastisitas. 


\section{- Uji Multikolinearitas}

Hasil Uji Multikolinearitas

\begin{tabular}{|l|c|}
\hline \multicolumn{1}{|c|}{ Variabel } & Centered VIF \\
\hline LNPDBIRN & 2,45 \\
\hline LNKURS & 2,486 \\
\hline INFINA & 1,042 \\
\hline
\end{tabular}

Hasil Uji Multikolinearitas ditunjukkan nilai Centered VIF varibel PDB Iran sebesar 2,45, kurs dolar AS sebesar 2,486, dan inflasi Indonesia sebesar 1,042 yang masing-masing nilainya kurang dari 10. Artinya, tidak terjadi multikolinearitas pada ketiga variabel independen tersebut.

\section{- Uji Autokorelasi}

Hasil Uji Autokorelasi

\begin{tabular}{|l|c|l|r|}
\hline F-statistic & 2,34 & Prob. F(3,41) & 0,087 \\
\hline Obs*R-squared & 7,018 & Prob. Chi-Square (3) & 0,071 \\
\hline
\end{tabular}

Hasil uji autokorelasi yang menggunakan Breusch-Godfrey Serial Correlation LM Test menunjukkan bahwa nilai probabilitas F statistik, yaitu 0,071 yang lebih besar dari tingkat alpha 0,05 (5 persen). Artiya, tidak terjadi autokorelasi.

\section{Pembahasan}

1. Koefisien regresi PDB Iran sebesar 0,307 dan nilai probabilitasnya sebesar 0,025 yang kurang dari a (0.05 persen), maka memiliki hubungan positif dan signifikan. Artinya, setiap perubahan kenaikan PDB Iran sebesar 1 persen, maka ekspor Indonesia ke Iran akan mengalami kenaikan sebesar 0,307 persen, dengan asumsi variabel independen yang lain dianggap konstan (ceteris paribus). Tentunya, hasil ini juga sesuai dengan acuan teori variabel PDB Iran berpengaruh positif terhadap ekspor Indonesia ke Iran.

2. Koefisien regresi kurs sebesar $(-2,612)$ dan nilai probabilitasnya sebesar 0,0000 yang kurang dari $\alpha$ (0.05 persen), maka memiliki hubungan negatif dan signifikan. Artinya, setiap perubahan kenaikan kurs sebesar 1 persen, maka ekspor Indonesia ke Iran akan mengalami penurunan sebesar 2,612 persen, dengan asumsi variabel independen yang lain dianggap konstan (ceteris paribus).

Hasil penelitian justru menunjukkan perbedaan dengan teori sebelumnya bahwa kurs berpengaruh positif terhadap nilai ekspor. Hasil serupa juga 
ditemukan di penelitian lain, misalnya volatilitas nilai tukar dolar AS berpengaruh negatif terhadap perdagangan internasional Iran, baik dalam jangka panjang maupun jangka pendek selama tahun 1961-2006 (Mahnaz D, dkk, 2012). Bahkan, Akmal (2018) dan Anshari dkk (2017) dalam penelitiannya juga mendapati hasil yang serupa karena disebabkan oleh beberapa faktor, di antaranya tingkat keterbukaan ekonomi negara eksportir atau negara importir, impor barang input produksi negara eksportir, dan keterbatasan metode analisis serta data lainnya.

Pada hasil penelitian Mahnaz D, dkk (2012), ditemukan salah satu faktor yang dapat menjelaskan hubungan negatif kurs dolar AS dengan perdagangan internasional Iran adalah pembatasan impor barang-barang ke Iran karena sanksi embargo, yang menyebabkan nilai mata uang Iran, Riyal, terhadap dolar AS menjadi tidak stabil. Untuk itu, transaksi perdagangan antara Indonesia dan Iran yang menggunakan dolar AS, sebagaimana temuan dalam penelitian ini yang tidak sejalan dengan teori sebelumnya diakibatkan pembatasan impor, yang sejalan dengan hasil penelitian Mahnaz D, dkk (2012).

3. Koefisien regresi inflasi Indonesia sebesar 0,078 dan nilai probabilitasnya sebesar 0,209 yang lebih dari $\alpha$ (0.05 persen), maka memiliki hubungan positif dan tidak signifikan. Artinya, setiap perubahan inflasi tidak mempengaruhi ekspor Indonesia ke Iran. Hasil penelitian ini tidak sesuai dengan acuan teori, karena beberapa kemungkinan, di antaranya penggunaan metode Ordinary Least Square yang masih dapat dikembangkan dengan menggunakan berbagai metode analisis lainnya sehingga diharapkan akan memperoleh hasil korelasi $r$ square yang lebih baik. Selain itu, rendahnya rata-rata tingkat inflasi Indonesia yang hanya berkisar 1,4 persen membuat inflasi tidak berpengaruh signifikan terhadap ekspor Indonesia ke Iran, terlebih fluktuasi inflasi Indonesia sendiri relatif cukup stabil. Hasil penelitian yang senada sebelumnya juga pernah terjadi pada penelitian Mutia dan Sasana (2015) dan Anshari dkk (2017), yakni inflasi Indonesia justru berpengaruh positif terhadap volume ekspor Indonesia, tetapi tidak signifikan.

\section{Simpulan}

Dari pengujian empiris penelitian ini terdapat beberapa temuan menarik terkait hubungan antara tiga variabel independen yaitu: PDB Iran, kurs dolar dan inflasi terhadap ekspor Indonesia ke Iran sebagai variabel dependennya. Berdasarkan faktor PDB Iran, hasilnya berpengaruh positif dan bersifat inelastis, yang berarti tren positif 
PDB Iran akan sejalan dengan tren positif ekspor Indonesia ke Iran. Dengan demikian, Iran berpotensi menjadi salah satu pasar tujuan ekspor Indonesia.

Adapun faktor kedua mengenai kurs dolar AS terhadap ekspor Indonesia ke Iran yang bersifat negatif dan elastis menunjukkan semakin tinggi kurs dolar AS, maka semakin rendah dorongan untuk ekspor Indonesia ke Iran. Begitupun sebaliknya, semakin turun kurs dolar AS, maka semakin tinggi ekspor Indonesia ke Iran. Hasil penelitian ini berbeda dari teori umum tentang pengaruh kurs dolar terhadap ekspor yang bersifat positif. Sebab, faktor-faktor ekonomi dalam kasus Iran sangat dipengaruhi oleh faktor-faktor non-ekonomi, terutama variabel sanksi yang mempengaruhi perdagangan internasional negara ini.

Faktor ketiga mengenai inflasi hasilnya tidak signifikan terhadap ekspor Indonesia ke Iran. Hal itu disebabkan salah satunya oleh penggunaan metode Ordinary Least Square yang kurang sesuai untuk menggambarkan hubungan antara inflasi Indonesia dengan ekspor Indonesia ke Iran. Oleh karena itu, perlu dipertimbangkan metode analisis dan data lainnya untuk memperoleh hasil korelasi $r$ square yang lebih baik. Meskipun penggunaan metode metode Ordinary Least Square dalam riset-riset sebelumnya sebagai metode yang tepat untuk mengukur pengaruh tingkat inflasi terhadap ekspor suatu negara ke negara lain, tapi untuk kasus Iran perlu dicari metode lain yang lebih tepat dan akurat, termasuk mempertimbangkan analisis politik yang cenderung lebih dominan dalam mempengaruhi perdagangan luar negerinya.

Keterbatasan penelitian ini yang sejak awal menggunakan analisis ekonomi dan tidak mempertimbangkan pendekatan non-ekonomi, terutama politik, menjadi pembuka jalan untuk penelitian lanjutan dengan menggunakan pendekatan mutidisiplin, khususnya, ekonomi politik internasional, dengan memasukkan variabel politik dalam menelisik pengaruh sanksi AS terhadap perdagangan Indonesia ke Iran, maupun sebaliknya.

Penelitian ini dengan segala keterbatasannya, terutama dari pendekatan yang murni ekonomi, memberikan sumbangan penting mengenai hubungan perdagangan Indonesia dan Iran dari aspek ekspornya yang potensial. Variabel kurs dolar yang tidak berkorelasi positif pada ekspor, karena faktor non-ekonomi seperti sanksi, membuka ruang baru untuk kemungkinan riset lanjutan mengenai alat pembayaran perdagangan kedua negara selain dolar, termasuk penggunaan mata uang masing-masing, maupun barter yang bisa dipertimbangkan oleh pengambil kebijakan kedua negara. 


\section{Daftar Pustaka}

Akmal, F. (2018). Analisis Faktor-faktor yang Mempengaruhi Nilai Ekspor (Studi Komparasi Indonesia-Amerika Serikat dan Indonesia-China). Skripsi, [online]. Dalam: http://digilib.unila.ac.id/31218 [Diakses 2 Oktober 2020].

Amir. (2003). Ekspor Impor Teori dan Penerapannya. Jakarta: PPM.

Anshari, MF dkk. (2017). Analisis Pengaruh Inflasi Terhadap Ekspor di Negara ASEAN 5 Periode tahun 2012-2016. Jurnal STAN, [online] 1(2). Dalam: http://jurnal.stan.ac.id/index.php/JIA/article/view/130 [Diakses 2 Oktober 2020].

Antaranews. (2019). Pengamat: Pasar Asia Jadi Potensi Tujuan Ekspor Indonesia. Antaranews, [online]. Dalam: https://www.antaranews.com/berita/1047044/pengamat-pasar-asia-jadi-potensitujuan-ekspor-indonesia [Diakses 7 April 2020].

Budiono. (1999). Teori Pertumbuhan Ekonomi. Yogyakarta: BPFE.

Christianto, E. (2013). Faktor yang Mempengaruhi Volume Impor Beras di Indonesia. Jurnal IBEKA, 7(2), 38-43.

CNBC Indonesia. (2018). Mengapa Dollar AS Masih Menjadi Kurs Acuan Dunia?. Dalam: https://www.cnbcindonesia.com/market/20180129135213-20-2814/mengapadolar-as-masih-menjadi-kurs-acuan-dunia [Diakses 6 April 2020].

Federal Reserve Economic Data, (2020). Indonesia, CPI, Quarterly [online]. Dalam: https://fred.stlouisfed.org/series/IDNCPIALLQINMEI [Diakses 15 Juni 2020].

Federal Reserve Economic Data. (2020), Indonesia, Exchange Rate, Quarterly [online]. Dalam: : https://fred.stlouisfed.org/series/CCUSSP02IDQ650N [Diakses 15 Juni 2020].

Hendrati, I, M., dan Yunita, D, S. (2012). Analisis Faktor Ekonomi yang Mempengaruhi Volume Ekspor Pada Saat Krisis di Indonesia. Skripsi, [online]. Dalam: http://ejournal.upnjatim.ac.id/index.php/rebis/article/view/31/21 [Diakses 1 Februari 2020].

Hidayat, P. (2016). Menelisik Hubungan Indonesia-Iran. Jurnal ICMES, [online] Dalam: https://icmes.org/politics/menelisik-hubungan-indonesia-iran/ [Diakses 1 Februari 2020].

Gujarati, D. (2003). Ekonometrika Dasar. Jakarta: Erlangga. 
International Chamber of Commerce. (2020). Incoterms Rules [online]. Dalam: https:// iccwbo.org/resource-for-business/incoterms-rules/incoterms-2020/ [Diakses 13 Juni 2020].

Iqbal, Muhammad. (2015). Pengolahan data dengan Regresi Linier Berganda (dengan Eviews). [online] Dalam: https://dosen.perbanas.id/wpcontent/uploads/2015/08/Regresi-Linier-Berganda-Eviews.pdf [Diakses 2 Oktober 2020].

Katadata.co.id (2020). Ancaman Sanksi Ekonomi AS untuk Iran dan Sejarahnya Sejak 1979 [online]. Dalam: https://katadata.co.id/berita/2020/01/09/ancaman-sanksiekonomi-as-untuk-iran-dan-sejarahnya-sejak-1979 [Diakses 6 Mei 2020].

Latumaerissa, J, R. (2012). Bank dan Lembaga Keuangan Lain. Jakarta: Salemba Kemlu Empat.

Mahnaz D, dkk. (2012). The Effect of Real Exchange Rate Instability on Non-Petroleum Exports in Iran [online]. Dalam: https://www.textroad.com/pdf/JBASR/J.\%20Basic. \%20Appl.\%20Sci.\%20Res.,\%202(7)6954-6961,\%202012.pdf [Diakses 24 April 2020].

Malian, A. H. (2016). Faktor-Faktor yang Mempengaruhi Ekspor Produk Pertanian dan Produk Industri Pertanian Indonesia: Pendekatan Macroeconomic Models dengan Path Analysis. Jurnal Agro Ekonomi, [online] 21(2). Dalam: https://scholar.google. $\mathrm{com} /$ scholar?hl=id\&as_sdt=0\%2C5\&q=malian+a+husni\&btnG=\#d=gs_qabs\&u=\%2 3p\%3Dv1WEyyrOTu8J [Diakses 2 Oktober 2020].

Mankiw, N, G. (2008). Makroekonomi. Ed.7. Jakarta: Erlangga.

Moin, B. (1999). Khomeini: Life of The Ayatullah. New York: Thomas Dunne Books.

Mutia, R. dan Sasana, H. (2015). Analisis Pengaruh Kurs, PDB, dan Tingkat Inflasi Terhadap Ekspor Indonesia ke Negara ASEAN (Studi pada Negara Malaysia, Singapura, Filipina, dan Thailand). Skripsi, [online]. Dalam: http://eprints.undip.ac.id/45461/ [Diakses 2 Oktober 2020].

Oktaviani, R dan Novianti, T. (2009). Teori Perdagangan Internasional dan Aplikasinya di Indonesia. Bogor: Departemen Ilmu Ekonomi FEM IPB.

Perdana, T. (2010). Analisis Faktor-Faktor yang Mempengaruhi Ekspor the PTPN. Skripsi, Bogor: Institut Pertanian Bogor.

Putong, I. (2010). Pengantar Mikro dan Makro. Ed 4. Jakarta: Mitra Wacana Media.

Salvatore, D. (1997). Ekonomi Internasional. Jakarta: Erlangga. 
68 | Husain, Sulistyono, Udjianto, Hidayat

Sobri. 2001. Ekonomi Internasional: Teori Masalah dan Kebijaksanaannya. Jakarta: BPFE-UI.

Sukirno, Sadono. 2012. Makroekonomi Teori Pengantar. Depok: Raja Grafindo Persada.

Silviana, H. (2016). Analisis Pengaruh Kurs dan Inflasi Terhadap Neraca Perdagangan di Negara-Negara Anggota Organisasi Kerja Sama Islam. Skripsi, [online]. Dalam: https://scholar.google.co.id/scholar?hl=id\&as_sdt=0\%2C5\&q=hield+silviana\&btnG $=[$ Diakses 2 Oktober 2020].

Statistical Center of Iran. (2020). Gross Domestic Product Iran. Dalam: https:// www.amar.org.ir/default.aspx [Diakses 15 Juni 2020].

Trade Map. (2020). Bilateral Trade Between Indonesia and Iran, Islamic Republic of Product: Total All Product. [online]. Dalam: https://www.trademap.org/Bilateral_MQ_TS.aspx?nvpm =1\%7c360\%7c\%7c364\%7c\%7cTOTAL\%7c\%7c\%7c2\%7c1\%7c1\%7c2\%7c2\%7c2\%7c1 \%7c1\%7c1\%7c1 [Diakses 15 Juni 2020].

World Bank. (2020). Islamic Republic of Iran overview. [online]. Dalam: https://www.worldbank.org/en/country/iran/overview [Diakses 25 April 2020]. 